\title{
Development and evaluation of a DNA-barcoding approach for the rapid identification of nematodes
}

\author{
Punyasloke Bhadury ${ }^{1,2,5, *}$, Melanie C. Austen ${ }^{1}$, David T. Bilton ${ }^{2}$, \\ P. John D. Lambshead ${ }^{3}$, Alex D. Rogers ${ }^{4}$, Gary R. Smerdon ${ }^{1}$ \\ ${ }^{1}$ Plymouth Marine Laboratory, Prospect Place, The Hoe, Plymouth PL1 3DH, UK \\ ${ }^{2}$ School of Biological Sciences, University of Plymouth, Drake Circus, Plymouth PL4 8AA, UK \\ ${ }^{3}$ Nematode Research Group, Department of Zoology, The Natural History Museum, Cromwell Road, London SW7 5BD, UK \\ ${ }^{4}$ Institute of Zoology, Zoological Society of London, Regent's Park, London NW1 4RY, UK
}

${ }^{5}$ Present address: Department of Geosciences, Guyot Hall, Princeton University, New Jersey 08544, USA

\begin{abstract}
Free-living nematodes are abundant in all marine habitats, are highly diverse, and can be useful for monitoring anthropogenic impacts on the environment. Despite such attributes, nematodes are effectively ignored by many marine ecologists because of their time-consuming taxonomy. Nematode diagnostics has traditionally relied on detailed comparison of morphological characters which, given their abundance, is difficult and laborious, meaning that the biodiversity of the group is typically underestimated. Molecular methods such as DNA-barcoding offer potentially efficient alternative approaches to studying the biodiversity of marine nematode communities, allowing these organisms to be more effectively exploited in ecological surveys and environmental assessments. In this study, a number of nuclear and mitochondrial genomic regions were evaluated as potential diagnostic loci for marine nematode species identification. Of these, the 18S ribosomal RNA gene amplified most reliably from a range of taxa, and was therefore evaluated as a DNA barcode. In a comparison of molecular and morphological identifications, over $97 \%$ of specimens sequenced were correctly assigned on the basis of a short stretch of $18 \mathrm{~S}$ rRNA sequence (approximately 345 $\mathrm{bp})$, making this a potentially useful marker for the rapid molecular assignment of unknown nematode species, and evaluation of nematode species richness during ecological surveys or environmental assessments. This study showed that a single marker approach based on amplification and sequencing may prove invaluable in the rapid identification of nematodes during ecological surveys and, indeed, other taxonomically challenging invertebrate taxa.
\end{abstract}

KEY WORDS: Marine nematodes - Identification . DNA barcoding $\cdot 18 \mathrm{~S}$ rRNA $\cdot$ Ecological survey

Resale or republication not permitted without written consent of the publisher

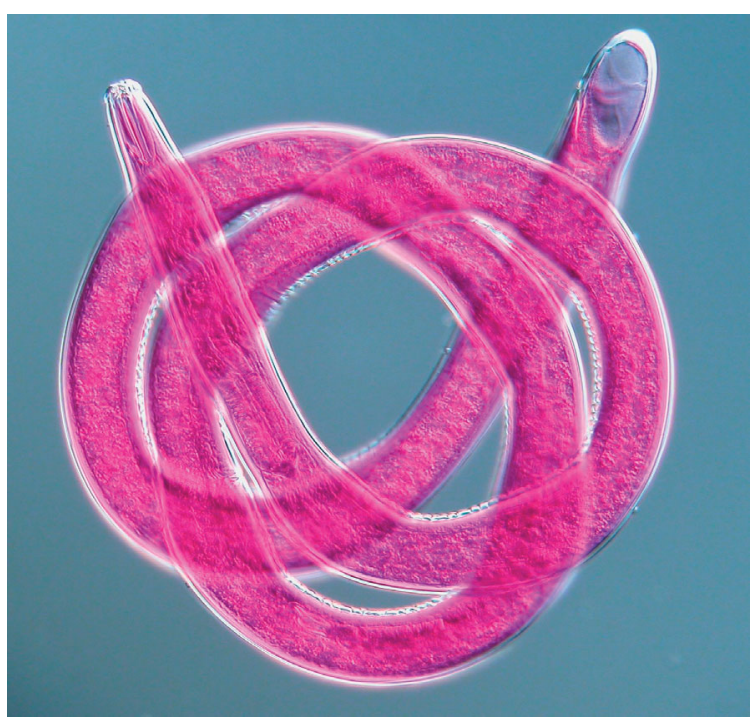

Genomic identification based on DNA barcoding was evaluated as a tool to improve identification of nematodes such as Trissonchulus sp. (photo). This method makes meiofaunal identification significantly easier and more reliable, particularly for non-experts in taxonomy, as well as in cases where traditional methods are impractical.

Photo: Dr. Tim Ferrero, The Natural History Museum, London, UK

\section{INTRODUCTION}

Sound taxonomy underpins almost all biological research, nowhere more so than in ecology. Despite this, there is currently a serious crisis in taxonomic expertise throughout the scientific commu- 
nity (Freckleton \& May 1992, Buyck 1999, Hopkins \& Frecklenton 2002), resulting in the neglect of many highly diverse groups of organisms. This is particularly the case for many marine invertebrate taxa, especially those from benthic sediments, which contain speciesrich communities of metazoans including large numbers of nematodes, polychaetes, crustaceans and molluscs (Grassle \& Maciolek 1992, Coull 1999, Lambshead 2004). Global marine nematode species richness may exceed 1 million (Lambshead 2004), only a few thousand of which are described, and these animals are typically the most abundant component of the meiofauna and deep-sea macrofauna (Lambshead 2004). Being so diverse and abundant, marine nematodes are believed to be of great importance ecologically as they play an important role in the decomposition process and recycling of nutrients (Austen 2004) and have proved to be highly sensitive indicators of anthropogenic stress in a range of situations (Lambshead 1986, Austen \& McEvoy 1997, Schratzberger et al. 2000). Despite such attributes, the group has seen relatively limited use by marine ecologists and those involved in routine biomonitoring, largely as a result of their relative taxonomic intractability. Specific identification of most marine nematodes relies on detailed morphological analysis (Platt \& Warwick 1988) that requires considerable taxonomic expertise, placing it outside the scope of most routine ecological surveys. Also, the overwhelming number of individuals present in a square metre of sediment $\left(1 \times 10^{5-7}\right.$; Lambshead 2004 ) impedes attempts to describe nematode communities in detail, even when such expertise is available. In addition to this, the fact that many taxa can also only be reliably identified from adult males has contributed to the relative neglect of nematodes in many infaunal studies (Warwick \& Robinson 2000). The use of morphologically-defined operational taxonomic units (or OTUs) on such organisms is also fraught with difficulty (Floyd et al. 2002). Defining discriminatory morphological characters in small, morphologically uniform families that are known to include taxa which are morphologically cryptic, in a manner which can be standardized across a range of investigators, is problematic even to the specialist.

DNA barcoding, based on the analysis of a small segment of the genome, is one potential way of simplifying and speeding up the evaluation and identification of taxa such as nematodes in ecological or biomonitoring studies (Hebert et al. 2003a, Rogers \& Lambshead 2004). Genomic regions within an individual can be viewed as genetic 'barcodes' as these regions hold necessary information from their remote or recent evolutionary history. Therefore a DNA barcode in the form of a specific sequence carries both species-specific and phylogenetic information regarding an organism
(Blaxter 2004). DNA barcodes can be used in the identification of unknown specimens, to assist the phylogenetic placement of unknown taxa through comparison with known reference sequences, and to enable the definition of molecular operational taxonomic units (MOTUs), whose delineation is not fraught with the difficulties discussed above. Such molecular barcodes are now routine in investigations of prokaryotic diversity (e.g. Cohan 2002), and have also been employed in unicellular eukaryotes, including some planktonic taxa (e.g. Massana et al. 2002, Moreira \& López-Garcia 2002). Identifications based on DNA sequences are also increasingly used for metazoans, including soil and parasitic nematodes, (Hebert et al. 2003a, Powers 2004) although to date this type of approach has seen limited application in marine systems.

This study investigated the potential utility of a nucleic acid marker for the rapid identification and evaluation of marine nematode diversity, based on a study of a wide range of taxa from estuarine and shelf waters around southwest Britain. In addition, the reliability of the barcoding approach was tested, by comparing the placement of specimens based on short DNA sequence with that generated by expert morphological identification of the same specimen as part of a broader ecological survey. An approach based on the amplification and sequencing of a short segment of DNA may prove invaluable towards rapid identification of nematodes and other benthic organisms.

\section{MATERIALS AND METHODS}

Sediment collection. Sediments were collected subtidally using a van Veen grab from muddy and muddysand substrates in SW England from the Tamar estuary $\left(50^{\circ} 24^{\prime} \mathrm{N}, 4^{\circ} 12^{\prime} \mathrm{W}\right)$ at 1 to $5 \mathrm{~m}$ depth, from Plymouth Sound at Jennycliff and Plymouth Breakwater (both $50^{\circ} 20^{\prime} \mathrm{N}, 4^{\circ} 08^{\prime} \mathrm{W}$ ) at 10 and $15 \mathrm{~m}$ depth, respectively, from Rame Head $\left(50^{\circ} 17^{\prime} \mathrm{N}, 4^{\circ} 17^{\prime} \mathrm{W}\right)$ at $50 \mathrm{~m}$ depth and from Cawsand $\left(50^{\circ} 19^{\prime} \mathrm{N}, 4^{\circ} 11^{\prime} \mathrm{W}\right)$ at $12 \mathrm{~m}$ depth. Additionally, sediment samples collected by hand from intertidal mud in the Plym estuary (Saltram) in SW England were also used in this study. All samples were immediately fixed in $1 \mathrm{l}$ storage pots containing $98 \%$ molecular grade ethanol (Hayman).

Meiofauna extraction and nematode identification. Each sediment sample was washed twice with tap water on a $63 \mu \mathrm{m}$ sieve, until the water passing through the sieve became clear, to remove finer sediment components and drive off any alcohol. Extraction then followed Somerfield \& Warwick's (1996) flotation method, where the residual sediment and fauna was saturated with Ludox ${ }^{\mathrm{TM}}$ (specific gravity 1.15) before being washed into $100 \mathrm{ml}$ beakers. The mixture of 
sediment and Ludox was thoroughly stirred and then left for at least $2 \mathrm{~h}$ to allow animals to become suspended. The supernatant was poured into a $63 \mu \mathrm{m}$ sieve to collect the fauna, which was then washed once with distilled water and stored in $98 \%$ alcohol. Nematode specimens used for DNA extraction were picked out of the extracted samples using a sterile needle under a stereo microscope $(50 \times$ magnification) and placed into a cavity block containing approximately $5 \%$ glycerol and $10 \%$ ethanol. Each specimen was then mounted in glycerol on a separate slide, and a cover slip placed on top and sealed with paraffin wax. Before mounting, slides and cover slips were washed in molecular grade alcohol and dried with tissues. Based on morphological characters, each specimen was identified to genus and species level (wherever possible) under a compound microscope, using pictorial keys for the identification of marine nematodes from North West Europe (Platt \& Warwick 1983, 1988). Wherever possible, male specimens were included for taxonomic conformation. All identifications were verified by experienced nematode taxonomists prior to molecular analyses. After identification, cover slips were removed from the slides using a sterile scalpel, and specimens were individually placed in $0.5 \mathrm{ml}$ PCR tubes containing $20 \mu \mathrm{l}$ of $0.25 \mathrm{M} \mathrm{NaOH}$ for DNA

Table 1. List of nematode taxa with family/order position (following Meldal's 2004 classification) and GenBank accession numbers

\begin{tabular}{|lll|}
\hline Taxon & Family/order & $\begin{array}{c}\text { Accession } \\
\text { number }\end{array}$ \\
\hline Daptonema setosum (Bütschli, 1874) & & Xyalidae \\
Daptonema sp. Cobb, 1920 & Xyalidae & AM234045 \\
Daptonema hirsutum (Vitiello, 1967) & Xyalidae & AM234624 \\
Theristus acer Bastian, 1865 & Xyalidae & AM236231 \\
Dorylaimopsis punctata Ditlevsen, 1918 & Comesomatidae & AM234047 \\
Sabatieria pulchra (Schneider, 1906) & Comesomatidae & AM234623 \\
Sabatieria celtica Rouville, 1903 & Comesomatidae & AM234626 \\
Setosabatieria hilarula (De Man, 1922) & Comesomatidae & AM236043 \\
Metachromadora remanei Gerlach, 1951 & Desmodoridae & AM234620 \\
Desmodora pontica Filipjev, 1922 & Desmodoridae & AM234628 \\
Spirinia parasitifera (Bastian, 1865) & Desmodoridae & AM236044 \\
Ascolaimus elongatus (Bütschli, 1874) & Axonolaimidae & AM234617 \\
Parodontophora sp. Timm, 1963 & Axonolaimidae & AM234630 \\
Axonolaimus helgolandicus Lorenzen, 1971 & Axonolaimidae & AM236598 \\
Paralinhomoeus sp. De Man, 1907 & Linhomoeidae & AM235216 \\
Terschellingia longicaudata De Man, 1907 & Linhomoeidae & AM234716 \\
Cyatholaimus sp. Bastian, 1865 & Cyatholaimidae & AM234618 \\
Praeacanthonchus sp. Micoletzky, 1924 & Cyatholaimidae & AM234046 \\
Oncholaimus sp. Dujardin, 1845 & Oncholaimidae & AM234625 \\
Bathylaimus sp. Cobb, 1894 & Tripyloididae & AM234619 \\
Anoplostoma sp. Bütschli, 1874 & Anoplostomatidae & AM235215 \\
Halichoanolaimus dolichurus Ssaweljev, 1912 & Choniolaimidae & AM234629 \\
Sphaerolaimus hirsutus Bastian, 1865 & Sphaerolaimidae & AM234622 \\
Adoncholaimus fuscus (Bastian, 1865) & Enoplidae & AM236232 \\
Adoncholaimus sp. Bastian 1865 & Enoplidae & AM236077 \\
Enoploides brunettii Gerlach, 1953 & Thoracostomopsidae & AM234621 \\
& & \\
\hline
\end{tabular}

extraction. Twenty-six taxa representing the major orders and groups of marine nematodes that dominate SW England benthic environments (Austen 1986, Austen \& McEvoy 1997) were morphologically identified prior to molecular analyses (Table 1).

Reliability of DNA barcodes for ecological surveys. To evaluate the reliability of identifications based on DNA barcodes, sediments from the Tamar and Plym estuaries were fixed in molecular grade ethanol, after which meiofauna were extracted as part of an ecological survey. Forty individuals from each site were randomly selected and fixed on slides for taxonomic identification. After taxonomic identification, unique numbers were assigned to each specimen and these randomised before being subjected to $18 \mathrm{~S}$ rRNA amplification and sequencing so that further analyses and processing acted as a 'blind test' of the barcoding. These sequences were then included in a phylogenetic analysis and their molecular and morphological placements compared. The identity of individual specimens based on morphological characters, and their unique reference numbers are given in Table 2 .

Molecular marker selection for this study. Two nuclear genes, namely 18S rRNA and 28S rRNA (for 28S rRNA primers see De Ley et al. 2005), were tested along with mitochondrial cytochrome C oxidase I (COI) and 16S rRNA genes (for primers see Hebert et al. 2003a, Bhadury 2005) for molecular barcoding evaluation. Further evaluation with the 28S rRNA, 16S rRNA and COI genes was abandoned as a result of unreliable PCR amplification with several representative marine nematode taxa from SW Britain. Therefore, the main focus of this work was to evaluate the potential of 18S rRNA genes for barcoding marine nematodes. In addition, 18S rRNA sequences are generally taxon specific and contain both conserved and variable regions, suitable for primer design and taxonomic distinction, respectively (Blaxter et al. 1998, Floyd et al. 2002). This gene is also present in multiple copies in the nematode genome and, therefore, is a more effective target for amplification than the single copy gene (Floyd et al. 2002).

DNA extraction from a single worm. DNA was extracted using a modification of the method of Floyd et al. (2002). All $0.5 \mathrm{ml}$ PCR tubes were frozen overnight ( 8 to $9 \mathrm{~h}$ ) at $-20^{\circ} \mathrm{C}$, then incubated overnight at $60^{\circ} \mathrm{C}$. The tubes were then heated for $3 \mathrm{~min}$ at $99^{\circ} \mathrm{C}$ on a 
Table 2. Morphological identifications and corresponding molecular tags for specimens used to test the barcoding concept

\begin{tabular}{|c|c|c|c|}
\hline \multirow{2}{*}{ 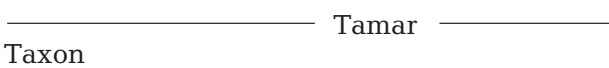 } & \multirow[b]{2}{*}{ Mol. ID } & \multirow[b]{2}{*}{ Taxon } & \multirow[b]{2}{*}{ Mol. ID } \\
\hline & & & \\
\hline Adoncholaimus fuscus Bastian, 1865 & Tamar1 & Praeacanthonchus sp. Micoletzky, 1924 & Plym1 \\
\hline Spirinia parasitifera (Bastian, 1865) & Tamar2 & Anoplostoma sp. Bütschli, 1874 & Plym2 \\
\hline Sabatieria sp. Rouville, 1903 & Tamar3 & Paracanthonchus sp. Micoletzky, 1924 & Plym3 \\
\hline Dichromadora sp. Kreis, 1929 & Tamar4 & Daptonema setosum (Bütschli, 1874) & Plym4 \\
\hline Terschellingia longicaudata De Man, 1907 & Tamar5 & Metachromadora sp. Filipjev, 1918 & Plym5 \\
\hline Praeacanthonchus sp. Micoletzky, 1924 & Tamar6 & Sabatieria pulchra (Schneider, 1906) & Plym6 \\
\hline Enoploides brunettii Gerlach, 1953 & Tamar7 & Terschellingia sp. De Man, 1888 & Plym7 \\
\hline Metachromadora remanei Gerlach, 1951 & Tamar8 & Sphaerolaimus hirsutus Bastian, 1865 & Plym8 \\
\hline Sphaerolaimus hirsutus Bastian, 1865 & Tamar9 & Theristus sp. Bastian, 1865 & Plym9 \\
\hline Sabatieria celtica Southern, 1914 & Tamar10 & Metachromadora sp. Filipjev, 1918 & Plym10 \\
\hline Atrochromadora microlaima (De Mann, 1889) & Tamar11 & Terschellingia sp. De Man, 1888 & Plym11 \\
\hline Terschellingia longicaudata De Man, 1907 & Tamar12 & Terschellingia longicaudata De Man, 1907 & Plym12 \\
\hline Terschellingia longicaudata De Man, 1907 & Tamar13 & Paralinhomoeus sp. De Man, 1907 & Plym13 \\
\hline Ascolaimus elongatus (Bütschli, 1874) & Tamar14 & Sphaerolaimus hirsutus Bastian, 1865 & Plym14 \\
\hline Terschellingia sp. De Man, 1888 & Tamar15 & Sphaerolaimus sp. Bastian, 1865 & Plym15 \\
\hline Viscosia viscosa (Bastian, 1865) & Tamar16 & Axonolaimus helgolandicus Lorenzen, 1971 & Plym16 \\
\hline Terschellingia longicaudata De Man, 1907 & Tamar17 & Metachromadora suecica (Allgén, 1929) & Plym17 \\
\hline Sabatieria celtica Southern, 1914 & Tamar18 & Daptonema sp. Cobb, 1920 & Plym18 \\
\hline Setosabatieria hilarula (De Man, 1922) & Tamar19 & Sabatieria sp. Rouville, 1903 & Plym19 \\
\hline Daptonema setosum (Bütschli, 1874) & Tamar20 & Daptonema hirsutum (Vitiello, 1967) & Plym20 \\
\hline Paralinhomoeus sp. De Man, 1907 & Tamar21 & Sabatieria sp. Rouville, 1903 & Plym21 \\
\hline Sabatieria pulchra (Schneider, 1906) & Tamar22 & Sabatieria sp. Rouville, 1903 & Plym22 \\
\hline Terschellingia longicaudata De Man, 1907 & Tamar23 & Enoploides sp. Ssaweljev, 1912 & Plym23 \\
\hline Desmodora pontica Filipjev, 1922 & Tamar24 & Adoncholaimus sp. Filipjev, 1918 & Plym24 \\
\hline Halichoanolaimus dolichurus Ssaweljev, 1912 & Tamar25 & Sphaerolaimus hirsutus Bastian, 1865 & Plym 25 \\
\hline Axonolaimus helgolandicus Lorenzen, 1971 & Tamar26 & Adoncholaimus sp. Filipjev, 1918 & Plym26 \\
\hline Adoncholaimus sp. Filipjev, 1918 & Tamar27 & Enoploides sp. Ssaweljev, 1912 & Plym27 \\
\hline Anoplostoma sp. Bütschli, 1874 & Tamar28 & Sphaerolaimus hirsutus Bastian, 1865 & Plym28 \\
\hline Terschellingia longicaudata De Man, 1907 & Tamar29 & Unnidentified Cyatholaimid & Plym29 \\
\hline Theristus acer Bastian, 1865 & Tamar30 & Theristus acer Bastian, 1865 & Plym 30 \\
\hline Paracanthonchus sp. Micoletzky, 1924 & Tamar31 & Metachromadora remanei Gerlach, 1951 & Plym31 \\
\hline Neochromadora sp. Micoletzky, 1924 & Tamar32 & Metachromadora remanei Gerlach, 1951 & Plym32 \\
\hline Metachromadora sp. Filipjev, 1918 & Tamar33 & Neochromadora sp. Micoletzky, 1924 & Plym33 \\
\hline Cyatholaimus sp. Bastian, 1865 & Tamar34 & Sphaerolaimus hirsutus Bastian, 1865 & Plym34 \\
\hline Daptonema normandicum (De Man, 1890) & Tamar35 & Paralinhomoeus sp. De Man, 1907 & Plym35 \\
\hline Daptonema oxycerca (De Man, 1888) & Tamar36 & Sphaerolaimus sp. Bastian, 1865 & Plym36 \\
\hline Terschellingia longicaudata De Man, 1907 & Tamar37 & Daptonema hirsutum (Vitiello, 1967) & Plym37 \\
\hline Metachromadora sp. Filipjev, 1918 & Tamar38 & Paralinhomeus sp. De Man, 1907 & Plym38 \\
\hline Praeacanthonchus sp. Micoletzky, 1924 & Tamar39 & Terschellingia sp. De Man, 1888 & Plym39 \\
\hline Terschellingia longicaudata De Man, 1907 & Tamar40 & Tripyloides sp. De Mann, 1886 & Plym40 \\
\hline
\end{tabular}

heating block and allowed to cool to room temperature before centrifugation for $30 \mathrm{~s}$ in a benchtop microcentrifuge $(16000 \times g) .4 \mu \mathrm{l}$ of $1 \mathrm{M} \mathrm{HCl}, 10 \mu \mathrm{l}$ of $0.5 \mathrm{M}$ Tris$\mathrm{HCl}(\mathrm{pH} 8.0)$ and $5 \mu \mathrm{l}$ of $2 \%$ Triton X-100 was added to each tube and the contents mixed briefly and centrifuged for $30 \mathrm{~s}(16000 \times g)$. Tubes were reheated for 3 min at $99^{\circ} \mathrm{C}$ and allowed to cool to room temperature. The extract was then used for PCR amplification.

Assembling 18S rRNA sequence database for barcoding evaluation. Two primers, namely MN18F (5'-CGCGAATRGCTCATTACAACAGC-3') and Nem 18S_R (5'-GGGCGGTATCTGATCGCC-3') were used to amplify approximately $925 \mathrm{bp}$ of the $18 \mathrm{~S}$ rRNA gene from 26 marine nematode taxa commonly found in SW England waters. The 18S rRNA sequence database is comprised of 26 taxa representing 4 major orders of the phylum Nematoda, which were tested in this study and subsequently used for identification of unknown nematodes from ecological surveys. To test the molecular barcoding concept in marine nematodes, a small fragment around $100 \mathrm{bp}$ inward from the 5' end of the 18S rRNA molecule was selected for evaluation. Two primers, MN18F forward and 22R reverse (5'GCCTGCTGCCTTCCTTGGA-3'), were used to amplify approximately 345 bp PCR fragments from 80 nematodes as part of the survey. The majority of these primers have been used previously in nematode phylogenetics and molecular identification studies (Floyd et al. 2002, 2005, Bhadury 2005).

Routine PCRs were conducted with $5 \mu$ of the extracted DNA, $5 \mu \mathrm{l} 10 \times$ buffer with $\mathrm{MgCl}_{2}, 5 \mu \mathrm{l}$ of $2 \mathrm{mM}$ deoxyribonucleotide triphosphates (dNTPs), $2 \mu \mathrm{l}$ of each primer $\left(10 \mathrm{pmol} \mathrm{l}^{-1}\right), 0.5 \mu \mathrm{l}$ of Taq DNA polymerase $\left(5 \mathrm{U} \mathrm{Hl}^{-1}\right)$ and water to make a total volume of $50 \mu \mathrm{l}$ for each sample. For MN18F and Nem_18S_R primers, the thermal cycler parameters were $95^{\circ} \mathrm{C}$ for $5 \mathrm{~min}, 37$ cycles of $95^{\circ} \mathrm{C}$ for $1 \mathrm{~min}, 54^{\circ} \mathrm{C}$ for $1 \mathrm{~min}$ and $72^{\circ} \mathrm{C}$ for $2 \mathrm{~min}$, and finally one cycle of $2 \mathrm{~min}$ at $55^{\circ} \mathrm{C}$, $5 \mathrm{~min}$ at $72^{\circ} \mathrm{C}$ followed by a holding temperature of $4^{\circ} \mathrm{C}$. For molecular barcoding evaluation, the following 
parameters were employed for MN18F and $22 \mathrm{R}$ primers: $95^{\circ} \mathrm{C}$ for $5 \mathrm{~min}$, followed by 37 cycles of $95^{\circ} \mathrm{C}$ for $30 \mathrm{~s}, 56^{\circ} \mathrm{C}$ for $1 \mathrm{~min}, 72^{\circ} \mathrm{C}$ for $1 \mathrm{~min} 30 \mathrm{~s}$ and a final extension of $72^{\circ} \mathrm{C}$ for $5 \mathrm{~min}$ and the PCR tubes were cooled at $4^{\circ} \mathrm{C}$. In total, 80 ind. from Saltram (Plym estuary) and Saltash (Tamar estuary) were PCR amplified and sequenced as part of an ecological survey towards barcoding evaluation.

Cloning and sequencing of the 18S rRNA gene. PCR fragments from the 26 marine nematode taxa were cloned with pBluescript $\mathrm{SK}^{-}$vector and the pGEM-T Easy vector system (Promega). Plasmid inserts were sequenced in both directions using the T7 and T3 primers for pBluescript $\mathrm{SK}^{-}$and $\mathrm{M} 13 \mathrm{~F}$ and M13R primers for pGEM-T vector. We sequenced 3 to 4 colonies from each clone to confirm the sequence identity. Sequence traces were checked with Chromas Pro software package (Technelysium) for any ambiguities and/or errors.

Sequence analysis and the reliability of barcode identification. 18S rRNA sequences from 26 taxa generated in this study were aligned in Clustal X (Thompson et al. 1997, Jeanmougin et al. 1998) using the default parameters. Neighbour-joining trees were constructed with Molecular Evolutionary Genetic Analysis (MEGA) v3.0 (Kumar et al. 2004) using gammacorrected Kimura distance parameters (Blaxter et al. 1998). Additionally, a $345 \mathrm{bp}$ fragment from the $18 \mathrm{~S}$ rRNA gene representing all the major 26 taxa were subjected to phylogenetic analysis using the parameters mentioned above. For molecular barcoding evaluation, 18S rRNA sequences (345 bp fragment) generated from known nematode taxa in this study, together with selected sequences from the GenBank and EMBL databases [only those whose identification was deemed reliable and published in Meldal (2004) and Cook et al. (2005) were selected; accession numbers AF047888, AY854202, AY854204, AY854209, AY854210, AY854212, AY854224, and AY854225], in addition to 80 sequences from the Tamar and Plym estuaries, were aligned in the Clustal-X program using the default parameters. Neighbour-joining trees were constructed with MEGA v3.0 (Kumar et al. 2004) using gamma-corrected Kimura distance parameters (Blaxter et al. 1998). Bootstrap support values for individual branches were generated using 1000 replicate searches.

\section{RESULTS}

\section{S rRNA sequence from representative marine nematode taxa}

Successful amplification and sequencing of the $18 \mathrm{~S}$ rRNA gene was achieved from 26 nematode taxa from SW England waters, with the majority of taxa possess- ing unique sequences. A distinct pattern of conserved and variable regions was observed in the $18 \mathrm{~S}$ rRNA molecule among all these taxa (see Appendix 1, available at www.int-res.com/articles/suppl/m320p001_ app.pdf). The partial 5' end of the 18S rRNA molecule exhibits a mix of conserved and variable regions that were later tested for molecular barcoding. Almost all sequences showed a similarity of $99 \%$ and above when compared with the nematode sequences available online in GenBank and EMBL databases. Twenty-six MOTU generated in this study agree with morphological taxon assignment for all the specimens. However, there were discrepancies at the phylogenetic level for some of the taxa based on 18S rRNA sequences (Fig. 1). These discrepancies are beyond the scope of this paper and are not discussed. Amplified taxa along with family/order position and respective GenBank accession number have been detailed in Table 1. Additionally, MOTU patterns generated on a small segment of the 18S rRNA molecule (345 bp fragment) were able to resolve most of the taxa but there were discrepancies for some taxa as mentioned earlier (Fig. 2).

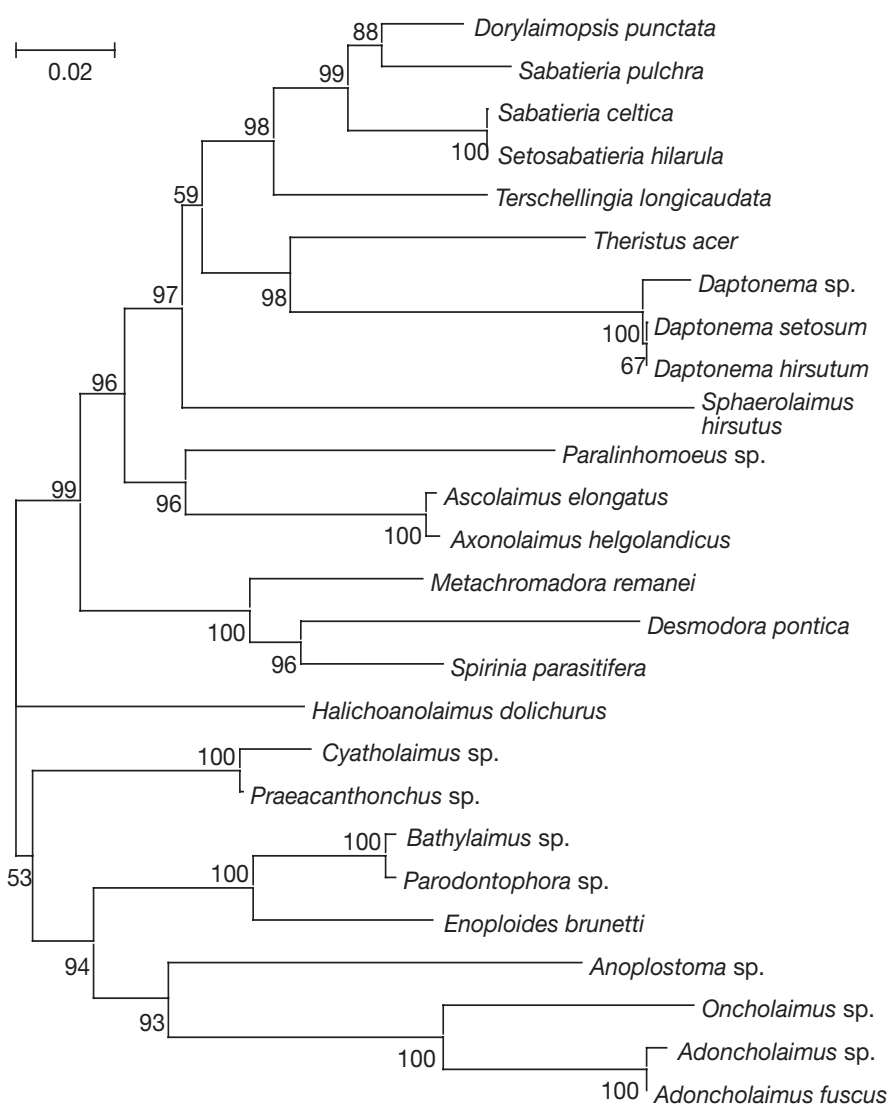

Fig. 1. Phylogenetic resolution (with bootstrap values; 1000 replicates) of representative marine nematode taxa from SW England waters, based on 18S rRNA sequences. Scale bar: 0.02 substitutions per site 


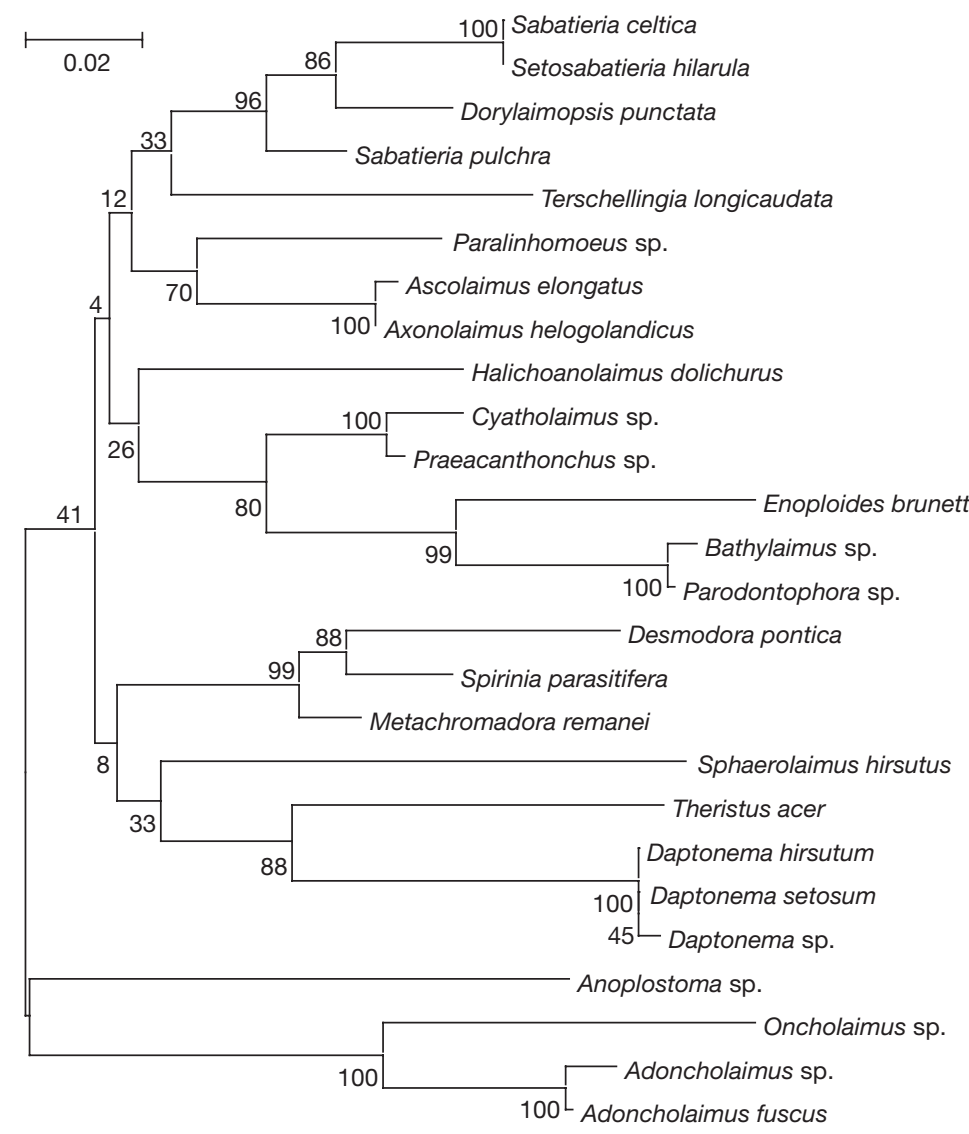

Fig. 2. Phylogenetic resolution (with bootstrap values; 1000 replicates) of representative marine nematode taxa from SW England waters, based on a $345 \mathrm{bp}$ fragment of the 18S rRNA molecule. Scale bar: 0.02 substitutions per site

\section{Molecular barcoding of marine nematodes based on 18S rRNA sequences}

Eighty high quality sequences were generated for nematodes from the Tamar and Plym estuaries that had been identified morphologically prior to DNA analyses. The phylogenetic analysis of the 80 sequences along with known marine nematode $18 \mathrm{~S}$ rRNA sequences (345 bp fragments) showed clear resolution, and the majority of the specimens were resolved to genus and species level in both the trees (Figs. 3 \& 4). From the Tamar estuary, only 1 specimen (Tamar 3) was not assignable to species level in the phylogenetic tree. This was placed within the genus Sabatieria on the basis of its 18S rRNA sequence, and indeed was identified as Sabatieria sp. based on morphological characters prior to molecular analysis. In the Plym estuary, 5 out of 40 specimens were not readily assignable to species level in the tree. Out of these, 2 were assignable to genus level as Praeacanthonchus (Plym1), and Sabatieria (Plym22), and had been identified as such based on morphological characters prior to molecular analyses. The Plym17 specimen was morphologically identified as Metachromadora suecica, and indeed clustered with the Metachromadora species included in the tree, despite being relatively divergent, differing by 7 base pairs from $M$. remanei. Plym19 and Plym29 clustered with Atrochromadora microlaima and Dichromadora sp. in the phylogenetic tree but had been morphologically identified as Sabatieria sp. and Cyatholaimid respectively. Sequences generated in this study have been submitted to GenBank and their accession numbers are DQ394725-DQ394804.

\section{DISCUSSION}

The main objective of this study was to amplify and sequence the 18S rRNA gene from representative estuarine and marine nematode specimens so as to create DNA sequence profiles which could be used to aid identification of bulk nematode samples. PCR products were recovered from all the individuals and there was no evidence of any complications with the molecular methods. Moreover, the alignment of the sequences and subsequent phylogenetic analysis was straightforward, as indels and polymorphism were uncommon for this gene. 18S rRNA genes were successfully amplified and sequenced from all the taxa tested, and proved to be valuable markers for barcoding studies. Wherever possible, more than one individual from each taxa was sequenced in this study and there was no variation at the intra-specific level between the members of each taxa for 18S rRNA gene. However, the 18S rRNA gene shows high inter-specific variation between taxa as expected. Such patterns have been observed across many metazoan phyla (Abouheif et al. 1998). The mix of conserved and variable regions amongst the 18S rRNA molecule makes it suitable for the design of primers to amplify segments of the gene that are variable amongst different species of nematodes.

Based on PCR amplification and sequencing success rates, the 18S rRNA gene proved to be more consistent as compared to other nuclear and mitochondrial genes. The 18S rRNA gene is generally conserved and has a high rate of amplification success with PCR, and because of this it has received a great deal of attention in recent literature as a barcoding locus (Floyd et al. 2002, Blaxter 2004, Powers 2004). In our study, a region from the $5^{\prime}$ end of the molecule of approximately 345 bp was selected for barcoding studies and evaluation of its potential to assign specimens to genus and 


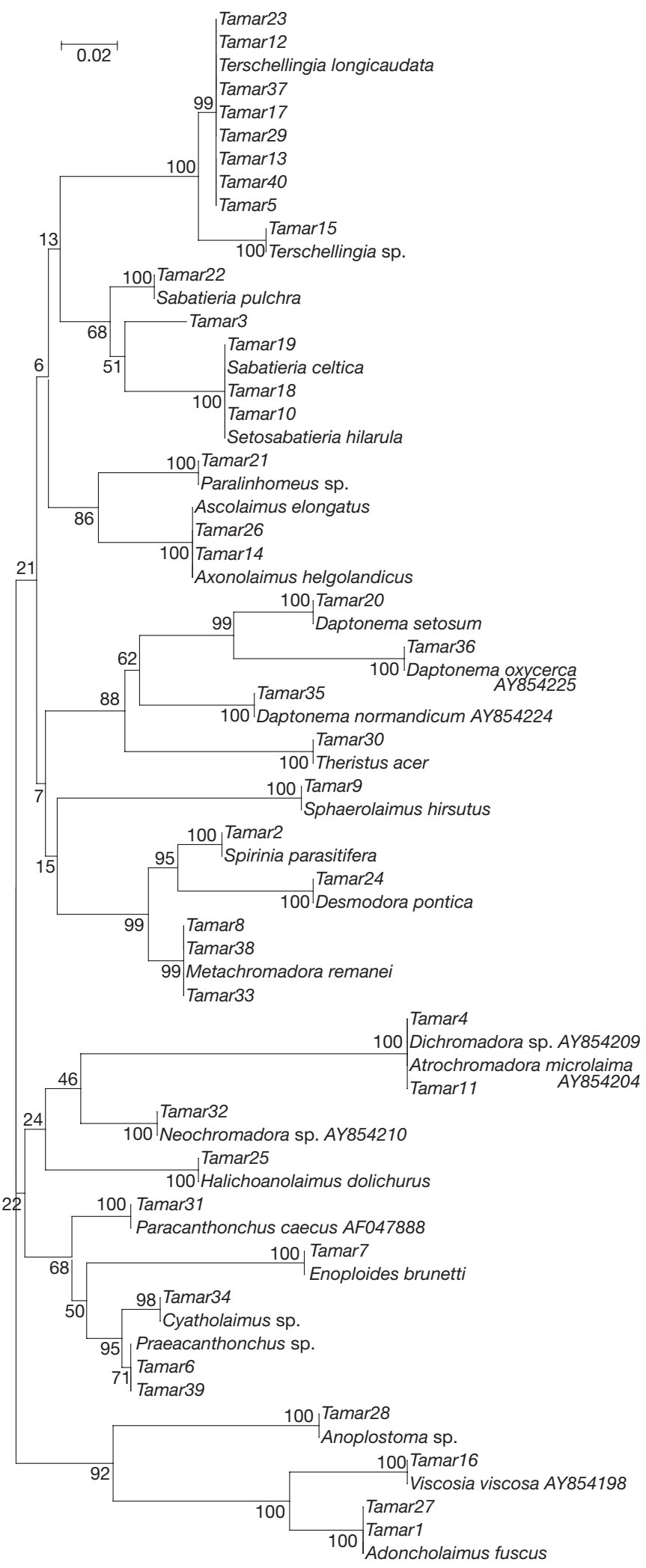

Fig. 3. Neighbour joining tree with bootstrap values $(1000$ replicates) showing relationship between Tamar estuary nematode 18S rRNA sequences and sequences from known marine nematodes. Scale bar: 0.02 substitutions per site

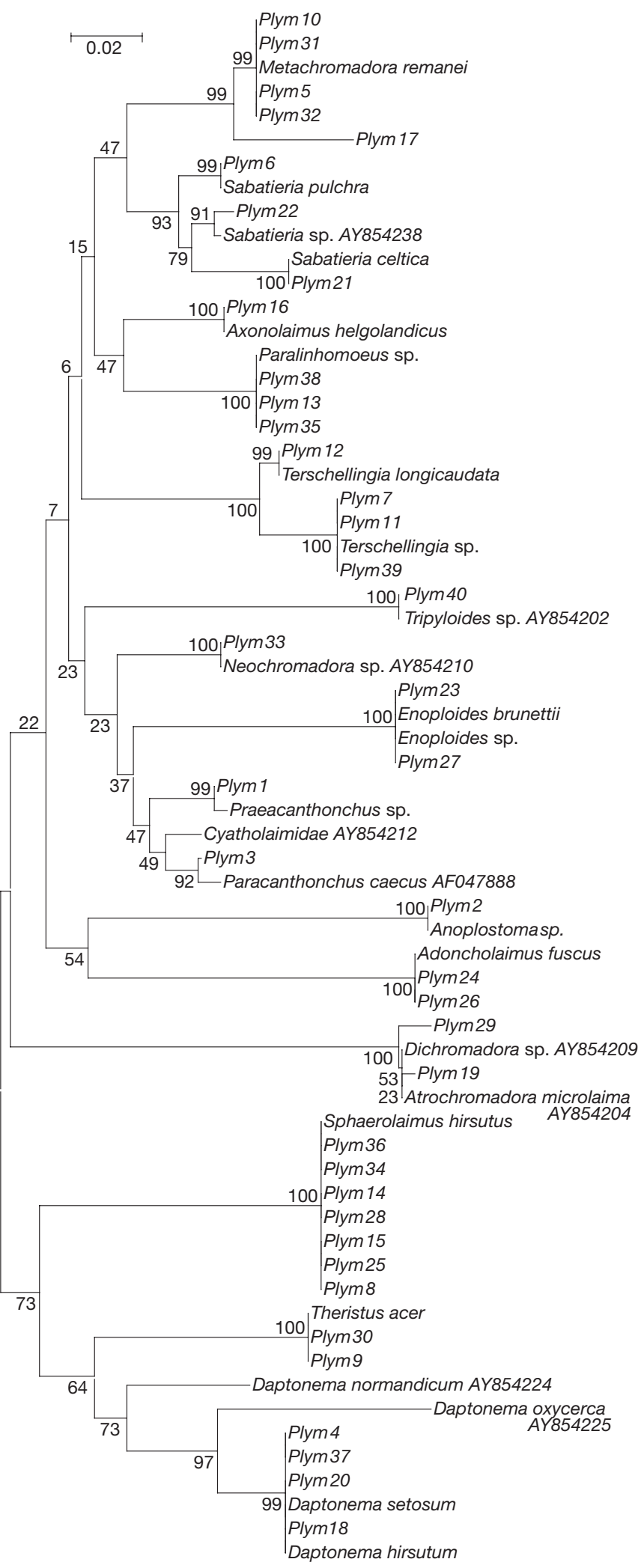

Fig. 4. Neighbour joining tree with bootstrap values $(1000$ replicates) showing relationship between Plym estuary nematode $18 \mathrm{~S}$ rRNA sequences and sequences from known marine nematodes. Scale bar: 0.02 substitutions per site 
species level. The validity of the technique was evaluated by identifying specimens using traditional taxonomic methods followed by their subsequent randomization, sequencing and inclusion in phylogenetic analysis. MOTU of almost all specimens from the Plym and Tamar estuaries resolved to genus and most of them to species level when compared with representative marine nematode sequences based on phylogenetic analysis. Additionally, the majority of the MOTUs were correctly assigned to genus and species level when compared to nematode sequences held online at GenBank and EMBL.

However there were some exceptions to this (see 'Results; Molecular barcoding of marine nematodes based on 18S rRNA sequences'), most notably for specimens Plym 19 and Plym 29. Misidentification caused as a result of distortion of morphological characters resulting from preservation of nematodes in ethanol or contamination of genomic DNA could have been responsible for the wrong derivation to genus or species level in the tree. Additionally, the possibility of novel cryptic taxa or sequences from previously undescribed species cannot be ruled out. Therefore, amplification and sequencing of other genomic regions for these 2 specimens could provide vital information for subsequent assignment to correct genus and species level.

Based on 18S rRNA amplification and sequencing, 78 MOTU out of 80 specimens were correctly assigned to genus or species level, indicating that the success rate of molecular barcoding using this sequence is close to $98 \%$. At the same time, taxonomic placements of most specimens using molecular data matched those based on morphology, where specimens were identified under the microscope and randomized subsequently to test the barcoding concept. The success rate of the 18S rRNA based DNA barcoding conducted here is consistent with the rate found by Hebert et al. (2003b) for COI across a wide range of Phyla. However, it is slightly lower than that of Hebert et al. (2003a) for nematodes where the success rate was $100 \%$ based on COI profiles. However, the number of terrestrial or parasitic nematode species analysed by Hebert et al. (2003b; not published online) was relatively limited (in the context of the broad range of nematode taxa found in the marine environment).

One of the important aspects of the molecular barcoding approach is to carefully consider the cut-off value generated from the bootstrap analysis for accurate genus and species level identification during large-scale ecological surveys. This study is based on a $345 \mathrm{bp} 18 \mathrm{~S}$ rRNA sequence and therefore bootstrap values of 99 and above would ideally correspond to correct genus and species level in a phylogenetic tree. Almost all of the unidentified specimens were correctly assigned to genus and species level when analysed against representative marine nematode taxa and, in the majority of the cases, the bootstrap values were either 99 or 100 (Figs. 3 \& 4).

A larger number of $18 \mathrm{~S}$ rRNA sequences from different marine nematode taxa are required for the barcoding approach to be more accurate and useful. The habitats chosen for this study (mud and muddy sand estuaries) are just one of the habitat types in which a diversity of nematode species are found. An everexpanding 18S rRNA sequence database will need to be developed to enable and speed up routine identification of nematodes from the full spectrum of marine habitats in which they exist. With the development of high throughput systems and an ever-expanding database of nematode sequences, molecular barcoding approaches may prove to be more time-efficient than traditional microscopy for faunal samples that are, in taxonomic terms, comparatively unknown, or poorly known (e.g. deep-sea samples). Molecular barcoding will be also useful in laboratories where nematode taxonomy expertise does not exist (i.e. throughout most of the world). Routine monitoring will ultimately require the development of mass screening methods such as massively parallel sequencing for speeding up barcoding process (Creer in press). At the same time, traditional taxonomic methods should continue to be used in order to develop keys for new species of marine nematodes so as to generate congruency between the 2 methods (molecular and morphological). This is especially the case for taxa for which amplification of the COI gene is not reliable or for which it does not provide species-level resolution. Traditional approaches may also be enhanced by new methods such as video capture or generation of digital images of nematodes from microscopes (e.g. De Ley \& Bert 2002).

Acknowledgements. Punyasloke Bhadury acknowledges Plymouth Marine Laboratory (PML) for the provision of a $\mathrm{PhD}$ Studentship. The authors would like to acknowledge Sarah Dashfield and Hazel Needham from PML for taxonomic assistance. This is a contribution to the PML Functional Biodiversity project.

\section{LITERATURE CITED}

Abouheif E, Zardoya R, Meyer A (1998) Limitations of metazoan 18S rRNA sequence data: Implications for reconstructing a phylogeny of the animal kingdom and inferring the reality of the Cambrian explosion. J Mol Evol 47:394-405

Austen MC (1986) Factors affecting meiobenthic community structure in the Tamar estuary. PhD thesis, University of Exeter

Austen MC (2004) Natural nematode communities are useful tools to address ecological and applied questions. Nematol Monogr Perspect 2:1-17 
Austen MC, McEvoy AJ (1997) The use of offshore meiobenthic communities in laboratory microcosm experiments: response to heavy metal contamination. J Exp Mar Biol Ecol 211:247-261

Bhadury P (2005) Molecular resolution of marine nematodes for improved assessment of biodiversity. PhD Thesis, University of Plymouth

Blaxter ML (2004) The promise of a DNA taxonomy. Philos Trans R Soc Lond B 359:669-679

Blaxter ML, De Ley P, Garey JR, Liu LX and 8 others (1998) A molecular evolutionary framework for the phylum Nematoda. Nature 392:71-75

Buyck B (1999) Taxonomists are an endangered species in Europe. Nature 401:321

Caldeira K, Wickett ME (2003) Anthropogenic carbon and ocean pH. Nature 425:365

Cohan FM (2002) What are bacterial species? Annu Rev Microbiol 56:457-487

Cook AA, Bhadury P, Debenham NJ, Meldal BHM, Blaxter ML, Smerdon GR, Austen MC, Lambshead PJD, Rogers AD (2005) Denaturing gradient gel electrophoresis (DGGE) as a tool for identification of marine nematodes. Mar Ecol Prog Ser 291:103-113

Coull BC (1999) Role of meiofauna in estuarine soft-bottom habitats. Aust J Ecol 24:327-343

Creer S (in press) New technologies. In: Lambshead PJD, Packer M (eds) Marine benthic nematode molecular protocol handbook. ISA Publications, Tucson, AZ

De Ley P, Bert W (2002) Video capture and editing as a tool for the storage, distribution, and illustration of morphological characters of nematodes. J Nematol 34:296-302

De Ley P, De Ley IT, Morris K, Abebe E and 8 others (2005) An integrated approach to fast and informative morphological vouchering of nematodes for applications in molecular barcoding. Philos Trans R Soc Lond B 360:1945-1958

Floyd R, Abebe E, Papert A, Blaxter ML (2002) Molecular barcodes for soil nematode identification. Mol Ecol 11:839-850

Floyd RM, Rogers AD, Lambshead PJD, Smith CR (2005) Nematode-specific PCR primers for the 18S small subunit ribosomal rRNA gene. Mol Ecol Notes 5:611-612

Gaston KJ, May RM (1992) Taxonomy of taxonomists. Nature 356:281-282

Grassle JF, Maciolek NJ (1992) Deep-sea species richness: regional and local diversity estimates from quantitative bottom samples. Am Nat 139:313-341

Hebert PDN, Cywinska A, Ball SL, deWaard JR (2003a) Biological identifications through DNA barcodes. Proc R Soc Lond B 270:313-321

Hebert PDN, Ratnasingham S, deWaard JR (2003b) Barcoding animal life: cytochrome $\mathrm{c}$ oxidase subunit 1 divergences among closely related species. Philos Trans R Soc Lond B 270:S96-S99 (Suppl)

Hopkins GW, Freckleton RP (2002) Declines in the numbers of amateur and professional taxonomists: implications for conservation. Anim Conserv 5:245-249

Editorial responsibility: Otto Kinne (Editor-in-Chief), Oldendorf/Luhe, Germany
Jeanmougin F, Thompson JD, Gouy M, Higgins DG, Gibson TJ (1998) Multiple sequence alignment with Clustal X. Trends Biochem Sci 23:403-405

Keddie EM, Higazi T, Unnasch TR (1998) The mitochondrial genome of Onchocerca volvulus: sequence, structure and phylogenetic analysis. Mol Biochem Parasitol 95:111-127

Kumar S, Tamura K, Nei M (2004) MEGA3: Integrated software for molecular evolutionary genetics analysis and sequence alignment. Brief Bioinform 5:150-163

Lambshead PJD (1986) Sub-catastrophic sewage and industrial waste contamination as revealed by marine nematode faunal analysis. Mar Ecol Prog Ser 29:247-260

Lambshead PJD (2004) Marine nematode biodiversity. In: Chen ZX, Chen Y, Chen SY, Dickson DW (eds) Nematology: advances and perspectives. Vol 1: Nematode morphology, physiology and ecology. CABI Publishing, Wallingford, p 436-467

Massana R, Guillou L, Díez B, Pedrós-Alió C (2002) Unveiling the organisms behind novel eukaryotic ribosomal RNA sequences from the ocean. Appl Environ Microbiol 68:4554-4558

Meldal BHM (2004) Phylogenetic systematics of the phylum Nematoda: evidence from molecules and morphology. University of Southampton

Moreira D, López-Garcia P (2002) The molecular ecology of microbial eukaryotes unveils a hidden world. Trends Microbiol 10:31-38

Platt HM, Warwick RM (1983) Free-living marine nematodes. Part I. British Enoplids. Cambridge University Press, Cambridge

Platt HM, Warwick RM (1988) Free-living Marine Nematodes. Part II. British Chromadorids. Brill/Backhuys, Leiden

Powers T (2004) Nematode molecular diagnostics: from bands to barcodes. Annu Rev Phytopathol 42:367-38

Rogers AD, Lambshead PJD (2004) Molecular studies of nematode diversity; past, present and future. In: Cook R, Hunt DJ (eds) Proc Fourth Int Congr Nematol, 8-13 June 2002. Nematology Monographs and Perspectives Volume 2. Brill Academic Publishing, Hendon, VA

Schratzberger M, Rees HL, Boyd SE (2000) Effects of simulated deposition of dredged material on structure of nematode assemblages - the role of contamination. Mar Biol 137:613-622

Somerfield PJ, Warwick RM (1996) Meiofauna in marine pollution monitoring programmes: a laboratory manual. MAFF Directorate of Fisheries Research, Lowestoft

Thompson JD, Gibson TJ, Plewniak F, Jeanmougin F, Higgins DG (1997) The CLUSTAL_X windows interface: flexible strategies for multiple sequence alignment aided by quality analysis tools. Nucleic Acids Res 25:4876-4882

Warwick RM, Robinson J (2000) Sibling species in the marine pollution indicator genus Pontonema Leidy (Nematoda: Oncholaimidae), with a description of $P$. mediterranea sp.nov. J Nat Hist 24:641-662

Submitted: April 19, 2006; Accepted: July 26, 2006

Proofs received from author(s): August 14, 2006 